\title{
A literature Based Review of Process Oriented Public FinanCe
}

\author{
Guban, A.; MeZEi, Z. \& SANDOR, A.
}

Abstract: The public finance sector is a crucial part of the national economy. The steps of the economic processes of public sector organizations, the appearing phases and the explored processes constitute a unified system. These complex economic processes are ruled by strict regulations with a limited possibility for improvement. The demand for improving business (economic) processes has a very wide literature and is very popular even among public finance experts. The topic is very relevant today as there are a lot of debates and confusions regarding the boundaries and scope of methods. In this paper we would like to collect and systemize these process oriented tools and methods from a historical, - as well as - from a public finance point of view, researching the most important and influential academic journals. As the business focused approach of process improvement is inherently becoming attractive for public finance organizations, we also examine the service orientation of these methods and tools.

Key words: improvement, service process, management, public finance, public sector
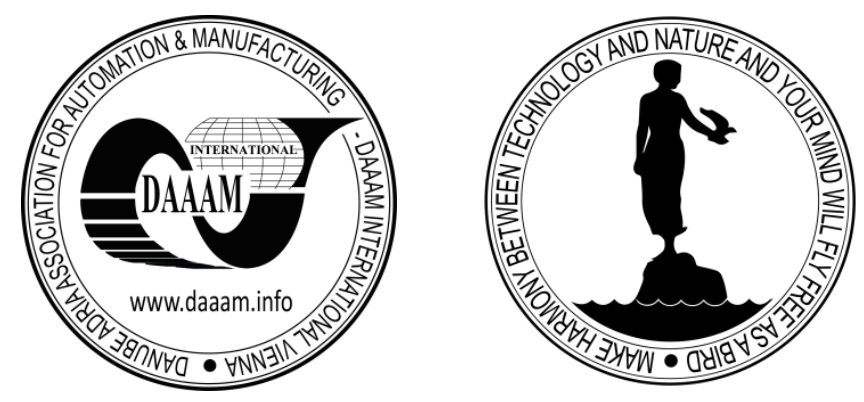

Authors' data: College professor, $\mathrm{PhD}$ Guban, $\mathrm{A}[\mathrm{kos}], \mathrm{PhD}$ candidate Mezei, Z[oltan], PhD student Sandor, A[gnes], Budapest Business School, Buzogany 11-13, H-1149 Budapest, Hungary, guban.akos@pszfb.bgf.hu

This Publication has to be referred as: Guban, A[kos]; Mezei, Z[oltan] \& Sandor, A[gnes] (2015). A literature Based Review of Process Oriented Public Finance, Chapter 10 in DAAAM International Scientific Book 2015, pp.117-126, B. Katalinic (Ed.), Published by DAAAM International, ISBN 978-3-902734-05-1, ISSN 17269687, Vienna, Austria

DOI: $10.2507 /$ daaam.scibook.2015.10 


\section{Introduction}

From the beginning of 21 st century, emerging number of scientific publications were published in the field of economic and management processes of public sector. It was not a novelty in scientific life, because we can observe such academic publications since the definition of 'state' had been considered in classic science of economy. In this paper we focus on service (logistic) processes and informatics aspects when analysing public sector. We disregard public finance, public administration and polity aspects of public sector, because those don't imply the mainstream of the on-going research - BGF EMMI-2630-2/2013/TUDPOL. We also kept our eyes on the attaching subjects that could be relevant, but limited our research to the public sector in all cases.

Despite this long and deep debate in the field of service process and management, there still remained much confusion amongst researchers and even experts. However there is a consensus about the need for the improvement of economic processes as the basis of the competition has moved from cost and quality to flexibility and responsiveness. The value of service process improvement is now being recognized in gaining sustainable competitive advantages in private economy, yet there is a serious lack of adapting these methods within public sector.

We delivered the review of scientific literature in two aspects: both the review of relevant Hungarian authors in the given period and the review of international publications as well. We examined the period between January 2000 and June 2015, and limited our search to the publications of high standard journals - where the impact factor is 0.8 or above. The most important journals are the following:

- Government Information Quarterly

- Journal of Development Economics

- Management Accounting Research

- Structural Change and Economic Dynamics

- Procedia - Social and Behavioural Sciences

We found 55,658 journal publications in the examined period focusing on service process with management keywords. We should highlight the year 2014 with 6,312 publications. If we limit our review to 'public sector' part, the result is 1,094 publication in complete. The linear trend curve shows mild ascent concerning to limited part. This means that scientific researchers are more active in the field of the public sector's economic processes despite the boundaries of service process amelioration. So, the on-going research faces new challenges when exploring the service processes and formulating proposals. The diagram below shows the published contents by years. 


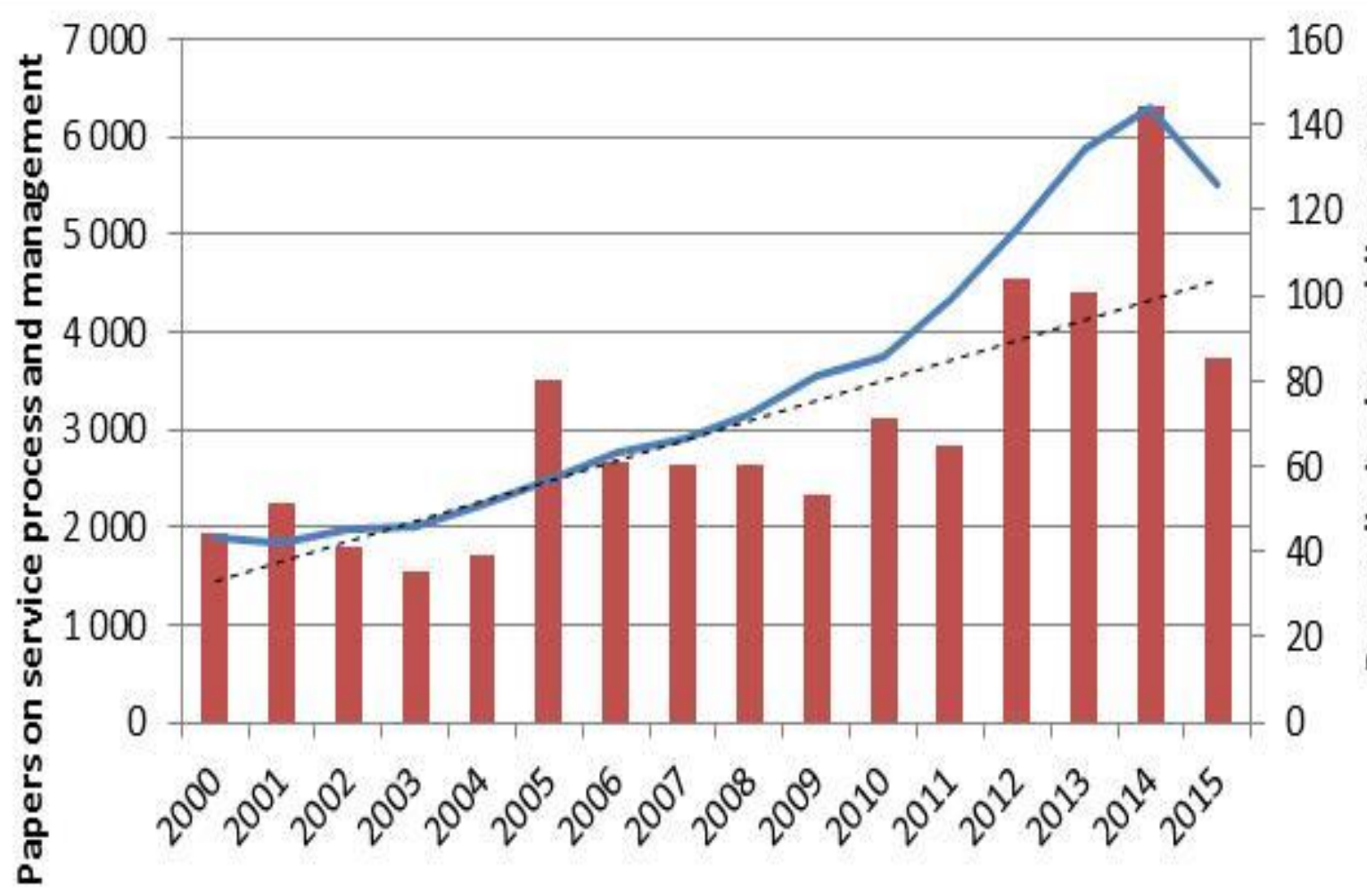

Number of papers limited to public sector

Number of papers on service process and management

....-. Linear trend (number of papers limited to public sector)

Fig. 1. Number of papers on service process, management and number of papers limited to public sector. Source: own editing

\section{Systematic literature review of public finance}

In our modern world public sector means one of the national economy's subsystem that ensures and produces public goods. The functions of public sector connect closely to the public policy's targets and methods all time. We can create several alignments in public sector according to the main features (Cullis - Jones, 2003). E.g. by economic frame: public finance, public utility, non-profit and public-private partnership.

In recent scientific literature several definitions and approaches can be observed regarding public goods, public wealth, public finance or other connecting terms. The phrase of 'goods' refers to material origin that generally meant value and/or propriety in history. Based on this connotation, not only material assets, buildings, cash or securities could be recognized as 'goods', but the known value of intangible assets as well. The latter comes from intellectual property in general that could build-up of the following: (a) intellectual capital of the country; (b) knowledge or qualification level of individuals; (c) health status of citizens (Sivák - Vígvári, 2012).

Several well-known researchers created definitions for public goods. Knut Wicksell, who lived in the 19th century, tried to extend the classic science of 
economy's analysis to public decision making. According to his arguments, the majority can easily create favourable public finance decisions to the stakeholders, but the sources of public expenditures will be levied to the minority (Wicksell, 1896). His publications had great impact on James Buchanan's researches, who worked-out the theory of public decisions. The state serves a double role, that of enforcing constitutional order and that of providing 'public goods'. This duality generates its own confusions and misunderstandings. 'Law', in itself, is a 'public good', with all of the familiar problems in securing voluntary compliance (Buchanan, 1975). In the middle of the 20th century Samuelson worked-out and standardized Lindahl's theory about public goods and finally he created the technological definition of public goods (Samuelson, 1954).

Below we describe the main definitions relating to public sector - based on Vígvári, 2006.

- State: (a) people living in a defined location ruled by common power, (b) public authority and public services ensured by government.

- Public goods: there isn't rivalry in the consumption of these goods and anybody cannot be ruled-out from the consumption.

- Public services: services of public utility without profit orientation for servicing common needs.

- Public funds: (a) a type of income that has been distracted from economic entities by laws and regulations, (b) service charges for the utilization of public goods.

- Fiscal management: the complete responsibility of managers in the public sector whose aim is the effective and result oriented execution of the fiscal year budget.

- External audit: state audit function based on laws and regulation that's independent from the given organization - e.g. state audit office or tax office.

Public funds and public wealth can be distinguished when examining public sector. Public funds aggregate the public expenditures and public income as two sides of balance in accounting. When distinguishing public and private sector in economy, it does not only mean governmental and private business. When talking about public sector's funds, we have to take into consideration the non-profit and also the for profit organizations financed by government. The economic results of these organizations have impact on public wealth provided by taxpayers: profit means increasing, loss means decreasing of public wealth (Csonka - Lehmann, 2000).

The diagram below describes the functional specification of 'state' as showing the context of definitions above.

The types of external audit on public funds can be specific (focusing on one or two economic area) or overall. The main objectives are the following: compliance, effectiveness or subservience. The main purpose of external audit is to protect public funds, because the definition above can be improved: (1) the flat rate fee for using public goods (e.g. highway fee) or (2) the revenue from the utilization of public goods - e.g. rental fee. The compliance aspects of external audit could be the compliance of budget execution or the compliance of taxation regulations. 


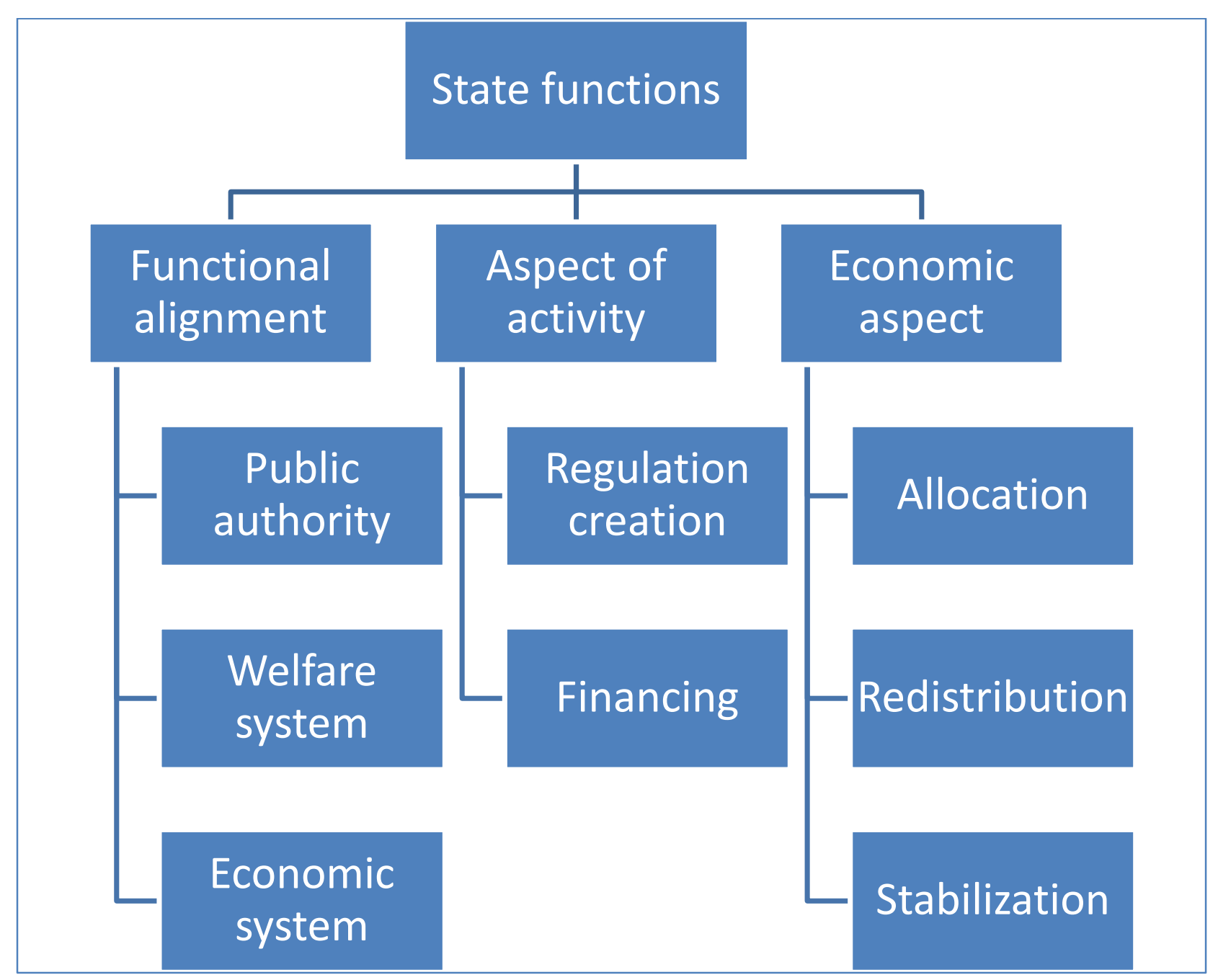

Fig. 2. Alignment of state functions. Source: own editing based on Zsugyel, 2009

\section{Systematic literature review of service process and management limited to public sector}

We examined the period between January 2000 and June 2015, and limited our search to the publications of high standard journals, where the impact factor is 0.8 or above. During the literature review of service process and management we focused on the following keywords: e-government, efficiency, motivation, performance measurement, innovation and public services.

Our aims are to identify the business process development methods and techniques in the public sector. During the research we realized that there are lots of suggestions to ameliorate the processes between the governments and citizens, but we did not find publications on methods of process improving and reengineering inside the organization.

Comparison with business processes with public services can be seen that the latter being more or less monopolies that are largely free from competitive pressures, moreover they are under political influence. The main difficulty in this field is that bureaucratic organisations and their civil servants are said to have no incentive to innovate because they operate in protected or monopolistic environments. Indeed, 
public organisations are said to be strongly risk averse and unwilling to experiment or risk failure (Djlellal - Gallouj - Miles, 2013).

A number of different types of innovations can be identified. Bloch - Brugge (2013) proposes the following typology of public innovations based on Windrum (2008):

- Service innovation,

- Service delivery innovation,

- Administrative and organisational innovation,

- Conceptual innovation,

- Policy innovation,

- System-like innovation.

Project managers have to have the same competences as in the business environment for the successful innovation. Public sector project managers work in a different environment which very often is not familiar with results-oriented project management, and are constantly dealing with political intervention in the management of projects and the challenges of working with political appointees (Kostelac-Matrljan - Dobovicek, 2011).

The main difference between organizations operating in public and private sectors is their owner. Unlike private companies, owned by entrepreneurs or shareholders, public organizations are owned collectively by members of political communities. Boyne (2002) mentions some arguments, which justify the difference between public organizations and business processes:

- Complexity (public organizations face a variety of stakeholders, each of whom places demands and constraints on managers);

- Permeability (public organizations are 'open systems' that are easily influenced by external events);

- Instability (political constraints result in frequent changes in policy, and the imposition of short time-horizons on public managers);

- Absence of competitive pressures (public organizations typically have few rivals for the provision of their services. Even when competition is present, public managers frequently enjoy a dominant position in the market, for example in education and health).

Public managers must follow public service ethic in their activities. Next key difference between public and private managers is that public managers must balance different needs and expectations of multiple stakeholders, among which we can mention politicians. Without having ethical competence, public managers cannot use their professional or political competences in right way (Jalocha et al, 2014).

In the public sector governments are looking for ways to reduce costs while at the same time to stimulate innovation. On the other hand governments face a major challenge to operate in a connected environment, engage stakeholders and solve societal problems by utilizing new methods, tools, practices and governance models. As result, fundamental changes are taking place on how government operates. 
Such changes are under the larger umbrella of 'lean government' (1-Government). Lean government is a new wave which is appearing as a response to traditional approaches-like electronic government (e-Government) and transformational government (t-Government), and aims at reducing the complexity of the public sector by simplifying and streamlining organizational structures and processes, at the same time at stimulating innovation by mobilizing stakeholders (Janssen - Estevez, 2013).

Furthermore the 1-Government helps to manage a network, bringing the right parties together and managing problem solving. To make l-Government possible, a set of enablers is needed. Two main enablers include: technological platforms (platforms) and capabilities to coordinate a complex network of collaborative entities. For 1Government there is a need to rationalize, reduce the complexity and decrease the variety of business processes that have been created by in the e-Government and tGovernment dawn. As with lean in the industry and services sectors, the focus is on eliminating waste (Janssen - Estevez, 2013).

'In e-government research, the service-dimension of e-services is frequently discussed (e.g. Goldkuhl, 2007 and Persson, 2009). In the e-government context, eservices typically deal with intangible goods such as exchange of information in order to receive permits, disbursements, register tax or similar. In fact, as some observers highlight, e-government represents the realization of an information intense government. Consequently, e-services become a matter of managing information and the relationship between governments and citizens becomes an information based relationship.' (Lindgren - Jansson, 2013)

The main target of e-Government is the development of user friendly and efficient services for citizens and business and semantic interoperability is a vital issue to solve within this domain. Currently the legal and e-Government Semantic Web applications are still in an experimental phase, but their potential impact on social, economic and political issues is extremely significant.

Web powered semantics could help the e-Government by engineering interoperable public administration procedures, facilitating the performance of daily routine procedures and helping inexperienced civil servants with new tasks, leading knowledge based government, in a knowledge based economy and society.

Public documents are structured by following certain rules and forms. The distinction of elements that each public document must possess is as follows:

- before main text elements,

- main text's elements and

- after main text elements.

'The Semantic Web provides a common framework that allows data to be shared and reused across application-, enterprise- and community boundaries. SW is important for the development and use of the digital content in heterogeneous networks and transforms a pre-existing network to a knowledge- and service-sharing environment.' (Savvas - Bassiliades, 2009)

It can be concluded that, the Semantic Web gives a solution to manage the public administration procedures with civil servants, but it could be also a problem solving tool for the internal processes in public organizations. 
The findings lead us to conclude that there are some tools to improve the processes in the public sector, but these tools provide solutions to handle problems between governments and citizens not the internal processes within the organization. Furthermore it could be seen that in public sector there is no processes which determined by process management methods, however it could be a solution for daily routine procedures, public administration procedures in internal processes of the organization. The next problem is the sequence of activities which is ad hoc type because of the lack of transparency. To tackle this difficulty data centres can be used for it.

\section{Conclusions and future perspectives for the research}

By reviewing past 15 years' scientific papers we found that significant number of articles have been published in the topics of services processes and management. And the numbers of publications show a mild emerging trend. Unfortunately, the examined papers handles public sector as an off-topic subject, so only tangential references can be observed by the aspects of informatics and service (logistics) processes.

These findings lead us to conclude that there is gap between service process and management regarding public sector. The reason is not only the lack of tools, but also the specific parameters of service processes. Human intervention is common practice in services, which results in a lot of hidden factors because of perceptions and competencies. Thus, the success of efficiency improvement in public sector depends very much on the fit to the external (laws) and internal regulations of public sector organizations.

One possible future orientation of the current research is to increase the efficiency of public finance by ameliorating the economic processes of public sector. Public administration means the management functions of public sector. The target of these process ameliorations is not cost cut in the public finance, but ensuring more effective operations in public sector.

The renewal of the competency system is in line with the performance improvement of polity. One part of public services needs to be recentralized (e.g. public healthcare system or public education), but other part needs to be more decentralized - e.g. environmental protection or water treatment. The latter could be delivered in regional base by powering the regional processes. Clear target setting-up and competent management is needed for utilizing the advantages of decentralization (Vígvári, 2006).

The review of the literature will be the basis of amelioration of much bounded service processes. We define much bounded service processes as there's limited possibility for amelioration because of internal (e.g. quality assurance) or external regulations - e.g. laws. There is no possibility to ameliorate the internal steps and elements of these processes, so we have to find other solutions to improve process efficiency of the system. One possibility is to swap (a) human resources, (b) assets or (c) transformations in the nods of the process. 
a) $\mathrm{HR}$ - improve the perceptions or 'ergonomic competency' by training;

b) Assets - all known methods of organizing technology can be used;

c) Transformation - take care that the input fluid and output fluid needs to be constant.

In case of transformation swap, the result should be a more effective transformation. We'll define efficiency later in this research by exact mathematical tools and we'll deliver the simulation model as well.

\section{References}

Bloch C, Bugge MM (2013): Public sector innovation - From theory to measurement. Structural Change and Economic Dynamics: 27 pp. 133-145

Boyne, G. (2002): Public and Private Management. What's the Difference? Journal of Management Studies: 39 pp. 97-122

Buchanan JM (1975): The limits to liberty - Between anarchy and leviathan. University of Chicago Press, Chicago.

Cullis J, Jones P (2003): Közpénzügyek és közösségi döntések.( Public finance and public choice) Aula Kiadó, Budapest.

Csonka G, Lehmann M (2000): A kormányzati szektor - új felfogásban. Pénzügyi Szemle 45 (The government sector - a new perception. financial Review )pp. 354-374 Djlellal F, Gallouj F, Miles I (2013): Two decades of research on innovation in services: Which place for public services? Structural Change and Economic Dynamics: 27 pp. $98-117$

Guban A (2014): Percepció, folyamat és entrópia, azaz szolgáltatási folyamatok BPA elmélete. (Perception, process and entropy, ie service processes BPA theory.) Prosperitas: 2 pp. 43-60

Guban A, Kasa R, Guban M (2014): The theory of perception driven process logistification. Eighteenth International Working Seminar on Production Economics, 24-28. February 2014, Innsbruck, Austria.

Goldkuhl G (2007). What does it mean to serve the citizen in e-services? - Towards a practical theory founded in socio-instrumental pragmatism. International Journal of Public Information Systems: 3 pp. 135-159

Jalocha B et al. (2014): Key competences of public sector project managers. Procedia - Social and Behavioral Sciences: 119 pp. 247-256

Janssen M, Estevez E (2013): Lean government and platform-based governance Doing more with less. Government Information Quarterly: 30(S1) pp. S1-S8

Kasa R, Guban A, Guban M, Hua NS, Molnar L (2014): The concept of perception driven service process reengineering by entropy reduction. Pannon Management Review: 3 pp. 11-54

Kostelac, D.; Matrljan, D. \& Dobovicek, S. (2011): Relationship between processes and project management. Annals of DAAAM for 2011 \& Proceedings of the 22nd International DAAAM Symposium, 23-26th November 2011, Vienna, Austria, 
Volume 22, No. 1, ISSN 1726-9679, ISBN 978-3-901509-83-4, Katalinic, B. (Ed.), pp. 1119-1120, Published by DAAAM International Vienna, Vienna

Lindgren I, Jansson G (2013): Electronic services in the public sector: A conceptual framework. Government Information Quarterly: 30 pp. 163-172

Persson A (2009): Förutsättningar för sammanhållen kommunal eFörvaltning. Liköpings universitet, Linköpings (Prerequisites for coherent local E Management. Linkoping University, Linkoping)

Samuelson P (1954): The pure theory of public expenditure. Review of Economics and Statistics: 36 pp. 387-389

Savvas I, Bassiliades N (2009): A process-oriented ontology-based knowledge management system for facilitating operational procedures in public administration. Expert Systems with Applications: 36 pp. 4467-4478

Sivák J, Szemlér T, Vigvári A (2013): A magyar államháztartás és az Európai Unió közpénzügyei. CompLex Kiadó, (The Hungarian government and the European Union's public finances. CompLex Publisher) Budapest

Sivák J, Vigvári A (2012): Rendhagyó bevezetés a közpénzügyek tanulmányozásába. CompLex Kiadó, (An unusual introduction to the study of public finances. CompLex Publisher) Budapest

Vigvári A (2006): A magyar gazdaság versenyképességét szolgáló közszektorhoz vezetö út egyik lehetséges forgatókönyve. (In Vigvári A (szerk): Vissza az alapokhoz, pp. 229-248) Új mandátum könyvkiadó, (One possible scenario for the public sector of the Hungarian economy, the competitiveness of the road. (In the Vigvári (ed). Back to basics, pp 229-248) New mandates publisher ) Budapest

Wicksell K (1896): New principle of just taxation. It was republished by Husgrave RT, Peacock AT (ed.) (1967) in Classic sin the theory of public finance. St. Martin's Press, New York

Windrum P (2008): Innovation and entrepreneurship in public services. (In Windrum P, Koch P. (eds): Public Sector Services: entrepreneurship, creativity and management, pp. 3-20) Edward Elgar, Cheltenham, Northampton.

Zsugyel J (szerk.) (2009): A közpénzügyek nagy kézikönyve. CompLex Kiadó, (A large public finances manual. CompLex Publisher ) Budapest 